\title{
Reverse the Red: achieving global biodiversity targets at national level
}

\author{
Jon PAUL RODRÍGUEZ
}

In late 2015, at the third global meeting of the leadership of the IUCN Species Survival Commission in Abu Dhabi, I asked the Commission's Group chairs what they wanted to achieve. As I was preparing a bid to head the Commission, my goal was to seek alignment between my vision and their expectations. The challenge ahead was monumental. The Species Survival Commission is the largest species expert network: it currently brings together over 10,000 members in 163 groups in 174 countries. Being able to deliver what the members wanted was paramount.

One after the other, chairs said the same thing. They were all proud of their work assessing taxa for the IUCN Red List of Threatened Species (IUCN, 2020). They understood the importance of quantifying extinction risk, and periodically reassessing it to estimate Red List indices (Butchart et al., 2007; Bubb et al., 2009). They expressed willingness and interest in continuing to do this, and did not have any plans to stop. However, they did not want to be remembered for measuring how close a species was to disappearing. They wanted to be remembered for saving species from extinction. The Red List is not of course an end in itself. It is the first step of a process that ultimately leads to conservation action. The Species Survival Commission can only succeed in its mission if, over time, trends such as those revealed by the Red List index (IPBES, 2019) are reversed.

For many years, the Commission's Cat Specialist Group had applied their Assess-Plan-Act framework: species assessments provided the data required for the creation of action plans, and these set the stage for donors to engage in implementing conservation action. Inspired by the Cat Specialist Group, we developed the Species Conservation Cycle, to provide a common framework for all the Commission's activities. In addition to the stages of Assess, Plan and Act, we added two transversal elements, Network and Communicate, to acknowledge the need to build and strengthen our expert network and ensure results were widely disseminated. A major challenge identified early on was that although the IUCN Red List of Threatened Species measures extinction risk at the global level, conservation action focuses primarily at the national or subnational level (Rodríguez, 2017).

Articles in the species assessments section of this issue of Oryx illustrate various aspects of the Species Conservation Cycle. Refinement of methods for estimation and monitoring

Jon Paul Rodríguez (ㅇ orcid.org/0000-0001-5019-2870) IUCN Species Survival Commission, Provita, and Instituto Venezolano de Investigaciones Científicas, Caracas, Venezuela. E-mail jonpaul.rodriguez@iucn.org of abundance and density are the building blocks of our knowledge of the changing status of species such as the leopard Panthera pardus (Devens et al., 2021), the Sunda clouded leopard Neofelis diardi (Mohamed et al., 2021), the Nilgiri tahr Nilgiritragus hylocrius (Suryawanshi et al., 2021) and the Bermuda skink Plestiodon longirostris (Turner et al., 2021). Collation and synthesis of data on distribution, threats and declines inform challenges such as that of the coexistence of people with the Asian elephant Elephas maximus in Sri Lanka (Fernando et al., 2021), the need to design protected areas for amphibians in Cameroon (Tchassem F. et al., 2021), and creating a regional strategy to counteract poaching of the South American river turtle Podocnemis expansa (Forero-Medina et al., 2021). Multi-species analyses, such as for tenrecs in Madagascar (Stephenson et al., 2021), take this work to the next level by using risk assessments to define priorities that guide conservation investment.

Governments are major actors in moving the species conservation agenda forward. Most human and financial resources available to conservation are not for investment at the global level, but targeted at communities that range from local to national, administered by individual countries. In contrast, the internal structure of the Species Survival Commission and the knowledge standards mobilized by the IUCN primarily organize globally (Brooks et al., 2015). This disconnect creates an opportunity for realignment of global sources of knowledge and expertise with local needs of conservation knowledge, plans and actions at the geographical scale of nations.

In this context, a new strategy-Reverse the Red-aims to mobilize local action in response to global priorities. It is a global movement to ignite strategic cooperation and action to ensure the survival of wild species and ecosystems. Led by the Species Survival Commission, the World Association of Zoos and Aquariums, HHMI Tangled Bank Studios, Smithsonian Institution Earth Optimism, On the Edge Conservation, and San Diego Zoo Global, and working in close collaboration with 18 additional partners, Reverse the Red will be launched at the next IUCN World Conservation Congress. Reverse the Red builds on existing capacity to develop national hubs in support of national strategies to meet commitments to biodiversity conventions such as the Convention on Biological Diversity, CITES, and the Convention on Migratory Species.

National Reverse the Red hubs will be decentralized, flexible and adaptive, led in each country through an institutional arrangement that builds on local strengths. Hosts 
of a national hub may be, for example, zoos, aquariums, botanical gardens or natural history museums, as they tend to be well-established organizations with solid local reputations. Alternatively, the convener could be a government agency, an academic institution, an IUCN member or an IUCN regional office. In all cases, taxonomically diverse national groupings of Species Survival Commission members will play a central role by providing the evidence and the knowledge that informs biodiversity conservation policies.

Reverse the Red will play out in four stages: (1) Partnerships (prior to the World Conservation Congress): founders agree on standardized tools and practices that define an umbrella mechanism for species and ecosystem conservation. (2) National rollout (at the World Conservation Congress): pilot countries create a national hub and initiate implementation. (3) Social movement (from the World Conservation Congress onwards): expansion to other communities with a diverse suite of optimism-driven, locally relevant pro-biodiversity educational resources, custom experiences, advocacy and behaviour change campaigns. (4) World Species Congress (by 2022): convene the first congress to report on and celebrate national progress in reversing declines of species and ecosystems.

We know how to do conservation. There are many examples of species that have been brought back from the brink of extinction by deliberate, planned interventions (CBSG, 2017; Mittermeier et al., 2017). However, far more money is spent on destroying nature than on protecting it. Reverse the Red focuses on shifting the balance-mobilizing scientific capacity and inspiring passion for nature conservation. I do not want to be remembered only for leading the most impressive and stimulating species conservation science network. I want to be remembered for working together with all of you in saving species-and succeeding.

\section{References}

Brooks, T.M., Butchart, S.H.M., Cox, N.A., Heath, M., Hilton-Taylor, C., Hoffmann, M. et al. (2015) Harnessing biodiversity and conservation knowledge products to track the Aichi targets and sustainable development goals. Biodiversity, 16, 157-174.

Bubb, P.J., Butchart, S.H.M., Collen, B., Dublin, H., Kapos, V., Pollock, C. et al. (2009) IUCN Red List Index-Guidance for National and Regional Use. IUCN, Gland, Switzerland.
Butchart, S.H.M., AkÇakaya, H.R., Chanson, J., Baillie, J., Collen, B., Quader, S. et al. (2007) Improvements to the Red List Index. PLOS ONE, 2, e140.

CBSG (Conservation Breeding Specialist Group) (2017) Second Nature: Changing the Future for Endangered Species. Conservation Breeding Specialist Group, St. Paul, USA.

Devens, C.H., Hayward, M.W., Tshabalala, T., Dickman, A., McManus, J.S., Smuts, B. \& Somers, M.J. (2021) Estimating leopard density across the highly modified human-dominated landscape of the Western Cape, South Africa. Oryx, 55, 35-46.

Fernando, P., De Silva, M.K.C.R., Jayasinghe, L.K.A., Janaka, H.K. \& PASTORINi, J. (2021) First country-wide survey of the Endangered Asian elephant: towards better conservation and management in Sri Lanka. Oryx, 55, 46-56.

Forero-Medina, G., Ferrara, C.R., Vogt, R.C., Fagundes, C.K., Balestra, R.A.M., Andrade, P.C.M. et al. (2021) On the future of the giant South American river turtle Podocnemis expansa. Oryx, 55, 74-81.

iPbeS (Intergovernmental Science-Policy Platform on Biodiversity and Ecosystem Services) (2019) Summary for Policymakers of the Global Assessment Report on Biodiversity and Ecosystem Services of the Intergovernmental Science-Policy Platform on Biodiversity and Ecosystem Services (eds S. Díaz, J. Settele, E. S. Brondízio, H.T. Ngo, M. Guèze, J. Agard et al.). IPBES Secretariat, Bonn, Germany.

IUCN (2020) IUCN Red List of Threatened Species. Version 2020-2. iucnredlist.org [accessed 13 November 2020].

Mittermeier, R.A., Rylands, A.B., Sechrest, W., Langhammer, P.F., Mittermeier, J.C., PARr, M.J. et al. (2017) Back from the Brink. CEMEX \& Earth in Focus, Qualicum Beach, Canada.

Mohamed, A., Sollmann, R., Wong, S.T., Niedballa, J., Abrams, J.F., Kissing, J. \& Wilting, A. (2021) Counting Sunda clouded leopards with confidence: incorporating individual heterogeneity in density estimates. Oryx, 55, 57-66.

Rodríguez, J.P. (2017) The difference conservation can make: integrating knowledge to reduce extinction risk. Oryx, 51, 1-2.

Stephenson, P.J., Soarimalala, V., Goodman, S.M., Nicoll, M.E., Andrianjakarivelo, V., Everson, K.M. et al. (2021) Review of the status and conservation of tenrecs (Mammalia: Afrotheria: Tenrecidae). Oryx, 55, 14-23.

Suryawanshi, K.R., Mudappa, D., Khanyari, M., Raman, T.R.S., Rathore, D., Kumar, M.A. \& Patel, J. (2021) Population assessment of the Endangered Nilgiri tahr Nilgiritragus hylocrius in the Anamalai Tiger Reserve, using the double-observer survey method. Oryx, 55, 67-73.

Tchassem F., A.M., Doherty-Bone, T.M., Kameni N., M.M., Tapondjou N., W.P., Tamesse, J.L. \& Gonwouo, L.N. (2021) What is driving declines of montane endemic amphibians? New insights from Mount Bamboutos, Cameroon. Oryx, 55, 24-34.

Turner, H., Griffiths, R.A., Outerbridge, M.E. \& Garcia, G. (2021) Estimating population parameters for the Critically Endangered Bermuda skink using robust design capture-markrecapture modelling. Oryx, 55, 82-89. 